\title{
Implementasi Kepemimpinan Ketua Himpaudi Dalam Penguatan Kompetensi Guru PAUD Di Kota Sukabumi
}

\author{
Asep Munajat ${ }^{1}$, Ibnu Hurri ${ }^{2}$ \\ Universitas Muhammadiyah Sukabumi ${ }^{1,2}$ \\ Jl. R. Syamsudin, S.H. No. 50 Kota Sukabumi, Telp. (0266) 218345 \\ Email: munajatasep@ummi.ac.id ${ }^{1}$, abangurie@ummi.ac.id ${ }^{2}$
}

\begin{abstract}
This article discusses the HIMPAUDI chairperson's leadership role, transformative and inspirational leadership on the essence of effective leadership in overcoming PAUD teachers low skills with the goal of improving PAUD teachers skills. HIMPAUDI is an agency that accommodates non-formal educators whose role is to improve PAUD educators competence. A qualitative approach is an approach used in this research, which is an approach that does not include statistics, but in the form of words, pictures, etc. In this analysis, the researcher emphasizes the aspect of the researcher as the main tool of testing, while at the same time paying attention to the methodology used, so that the findings are in line with expectations. Research results (1) In general, HIMPAUDI was created to help the government handle activities that due to limited human resources could not be done. (2) Chairman Himpaudi of Sukabumi City made short, medium and long-term work plans with increased teacher skills, including the proposed inclusion of scholarship funds in Sukabumi City RAPBD to encourage some PAUD teachers to increase their educational skills free of charge. (3) The approach used by the Head of Himpaudi is to develop the skills of PAUD teachers through training, training, and seminars, including basic and secondary training, which is carried out on a routine basis each year.
\end{abstract}

Keywords: Leadership, Teacher Competence, Himpaudi

\begin{abstract}
Abstrak
Artikel ini membahas mengenai peran kepemimpinan ketua HIMPAUDI, kepemimpinan yang transformasional dan karismatik tentang sifat kepemimpinan yang efektif dalam mengatasi rendahnya kompetensi yang dimiliki guru PAUD dengan tujuan untuk memperkuat kompetensi guru PAUD. HIMPAUDI merupakan organisasi yang mewadahi Pendidik nonformal yang salah satu kewajibannya untuk meningkatkan kompetensi pendidik PAUD. Pendekatan yang digunakan dalam penelitian ini merupakan pendekatan kualitatif, yaitu pendekatan yang tidak mengandung angka-angka, melainkan berupa kata-kata, gambar, dan sebagainya Dalam penelitian ini, peneliti menekankan pada faktor peneliti sebagai alat penelitian utama, disamping memperhatikan metode yang digunakan, agar hasilnya sesuai dengan apa yang diharapkan. Hasil dari penelitian (1) Secara umum HIMPAUDI dibentuk untuk membantu pemerintah menangani tugas-tugas yang tidak mungkin dapat dilakukan karena keterbatasan sumber daya manusia. (2) Ketua Himpaudi kota Sukabumi membuat rencana kerja jangka pendek, menengah dan panjang yang berisikan peningkatan kompetensi guru diantaranya mengusulkan masuknya angaran beasiswa di RAPBD kota sukabumi sehinggan beberapa guru PAUD dapat meningkatkan kulaifikasi pendidikanya secara gratis. (3) Motode yang dilakukan ketua himpaudi untuk meningkatkan kompetensi guru PAUD Blewat pelatihan, pelatihan dan workshop diantaranya diklat dasar dan menengah yang secara rutin dilaksanakan tiap tahun.
\end{abstract}

Kata kunci : Kepemimpinan, kompetensi guru, Himpaudi.

\section{PENDAhUluan}

Pendidikan Anak Usia Dini (PAUD) merupakan pendidikan yang sangat mendasar yang penting untuk pertumbuhan masa depan anak. PAUD bertujuan memaksimalkan perkembangan berbagai kemampuan anak sesuai dengan kemampuan anak dalam semua aspek perkembangan dan 
pertumbuhan, termasuk aspek nilai-nilai moral agama, motorik fisik, mental, bahasa, emosi sosial dan seni sejalan dengan tahap perkembangan anak. (Kemendikbud, 2014). PAUD diselengarakan melalui jalur formal, non-formal dan informal dengan berbagai program yang dilaksanakan secara kontekstual sebagai langkah pertama dalam pembinaan dan pengembangan yang ditujukan untuk anak-anak sejak lahir hingga usia enam tahun, melalui penyediaan pendidikan.

Himpaudi merupakan organisasi/perkumpulan guru-guru PAUD non Formal yang bertujuan menghimpun seluruh guru PAUD non formal dalam rangka peningkatan kompetensi dan untuk mmembantu tugas-tugas yang tidak bisa dilaksankan oleh pemerintah. HIMPAUDI berpusat di kota Jakarta bertujuan untuk membina dan mengembangkan organisasi secara bertahap, mengakomodasi, memperjuangkan, dan mewujudkan aspirasi staf pendidik dan anak usia dini, serta memfasilitasi pengembangan profesi guru dan profesional pendidikan anak usia dini.

Untuk menjalankan roda kepemimpinan HIMPAUDI, diperlukan pemimpin yang mampu menggunakan pengaruhnya dalam mewujudkan dan mencapai tujuan organisasi, hal tersebut menekankan pentingnya menciptakan komunitas yang bertujuan untuk memfokuskan sumber daya organisasi pada tujuan yang disepakati. Keberlangsungan suatu organisasi tergantung dari bagaimana cara pemimpin/ketua dalam memimpin organisasi HIMPAUDI, dalam konteks ini, Bass (1996) mencatat bahwa kehadiran ketua HIMPAUDI dengan pola kepemimpinan transformasi sangat berpengaruh, khususnya dampak pemimpin terhadap anggota HIMPAUDI, variabel kepemimpinan ketua HIMPAUDI sangat berpengaruh pada kepercayaan, rasa hormat, kesetiaan organisasi, dan kemajuan atau mundur. Kepemimpinan yang karismatik dan transformatif dibedakan dari kepemimpinan transaksional, yang melibatkan proses pertukaran untuk memotivasi pengikut agar mematuhi tuntutan pemimpin dan aturan organisasi (Bass \& Avolio, 1990).

Seorang pemimpin harus senantiasa memiliki kepekaan tinggi yang mampu menciptakan pembaharuan secara efektif dan efisien, benar dan tepat sesuai dengan tantangan yang menghadang dan mempengaruhi kehidupan organisasi (Bass, 2000). Pengaruh fundamental seorang pemimpin harus melibatkan serangkaian interaksi dari waktu ke waktu, termasuk kepatuhan instrumental, identifikasi pribadi, dan internalisasi (Kelman, 1958). Proses pengaruh ini memberikan cara yang bermanfaat untuk menjelaskan pengaruh seorang pemimpin terhadap sikap, motivasi, dan perilaku bawahan. Pengaruh kepemimpinan ketua HIMPAUDI terhadap anggotanya bukan pengaruh pemimpin pada suatu kelompok atau proses organisasi, tetapi harus melalui pendekatan yang sifatnya memahami kondisi anggotanya. Pengertiannya adalah bagaimana seorang pemimpin harus dapat mengembangkan rencana yang dapat mempengaruhi efikasi diri atau motivasi anggota, kepercayaan diri, dan dedikasi yang ditingkatkan untuk pekerjaan guru PAUD (Hunt, 1991).

Contoh-contoh proses tingkat tim tertentu meliputi: (1) seberapa baik staf dan aset bekerja telah diorganisasi; (2) seberapa baik tugas kelompok yang saling terkait terkoordinasi; (3) jumlah tujuan dan sasaran persetujuan anggota; (4) rasa saling percaya dan kerja sama antara anggota; (5) tingkat identifikasi anggota dengan kelompok; (6) kepercayaan anggota dalam kapasitas kelompok untuk mencapai tujuannya; (7) akuisisi dan pemanfaatan sumber daya yang efektif; dan (8) kerjasama strategis dengan pihak internal dan institusional lainnya (Yukl, 1998). HIMPAUDI Kota Sukabumi mulai bergerak pada tahun 2011. yang dijabat oleh Dewi Agustiana, M.Pd, dan menunjukkan perubahan yang lebih baik dalam upaya peningkatan kompetensi pendidik dan tenaga kependidikan. Sininergi dengan pemerintah merupakan usaha yang dilakukan bersama untuk meningkatkan kompetensi dan kulaitas pendidik dan tenaga kependidikan. Hal tersebut terus dikembangkan melalui sosialisasi PAUD non formal yang mendapat legalitas dari Pemerintah Kota Sukabumi. kehadiran lembaga PAUD non-formal mulai dilihat sebagai lembaga pendidikan alternatif yang mudah diakses, sederhana, dan ramah keluarga dalam memenuhi keinginan orang tua untuk menempatkan anak-anak mereka di lembaga sesuai dengan kemampuan mereka.

Setiap tahunya anggota HIMPAUDI bertambah, artinya tanggung jawab secara pribadi maupun lembaga untuk meningkatkan pengetahuan pendidik harus terus dilakukan. Untuk memenuhi kompetensi pendidik PAUD non formal, salah satu yang harus dikuasai oleh para pendidik dan tenaga kependidikan yaitu kompetensi guru, yang merupakan syarat penting tercapainya tujuan pendidikan di PAUD. Seorang pendidik yang memiliki profesionalisme tinggi akan tercermin dalam sikap mental serta komitmennya terhadap perwujudan dan peningkatan kualitas profesional melalui berbagai cara dan strategi (Basrowi \& Soenyono, 2007). Berikut ini adalah data pendidik dan tenaga kependidikan PAUD non formal di Kota Sukabumi. 
Tabel 1. Jumlah lulusan pendidik PAUD Kota Sukabumi

\begin{tabular}{ccccc}
\hline No & Lulusan & Jumlah & Dalam $\%$ & Kesimpulan \\
\hline 1 & S2 (tidak Linier) & 9 & 0,8 & \\
2 & S1 (tidak Linier) & 304 & 27,6 & \\
3 & S1 (Linier) & 10 & 0,9 & Yang Linier \\
4 & D3 & 95 & $8,9 \%$ & \\
5 & D2 & 90 & 8,1 & \\
6 & D1 & 97 & 8,8 & \\
7 & SMA & 480 & 44 & Yang tidak \\
8 & SMP & 13 & 1,1 & linier 99, $\%$ \\
9 & SD & 2 & 0,1 & \\
\hline
\end{tabular}

Sumber : Pengurus daerah HIMPAUDI Kota Sukabumi (2018)

Data tersebut menunjukan bahwa guru-guru PAUD non formal di kota sukabumi belum sepenuhnyha memiliki kompetensi profesionalisme seperti yang diatur oleh Peraturan Menteri Pendidikan dan Kebudayaan Republik Indonesia Nomor 137 pasal 25 tahun 2014 Standar Nasional Pendidikan Anak Usia Dini yang menyatakan bahwa pendidik seharusnya memliliki kualifikasi SI PAUD. Data menunjukkan 99,1\% tidak memenuhi kualifikasi sebagai pendidik PAUD, ini merupakan masalah yang harus segera di tindak lanjuti oleh pemerintah melalui HIMPAUDI sebagai mitra kerja. Pendidik dan tenaga kependidikan harus memenuhi standar dan kualifikasi pendidik dan tenaga kependidikan yang sesuai dengan peraturan tersebut agar dapat melaksanakan proses belajar mengajar di PAUD dengan benar, efisien, efektif dan menyenangkan (Uno, 2007). Selain data lulusan para pendidik dan tenaga kependidikan, peneliti juga memperoleh data tentang pendidik dan tenaga kependidikan yang telah mengikuti diklat berjenjang tingkat dasar dan lanjutan yang pernah diselenggarakan pada tahun 2013 dan 2016. Dari hasil pendidikan dan latihan ini, diperoleh jumlah 300 pendidik dan tenaga kependidikan pernah mengikuti diklat berjenjang tingkat dasar dan 24 pendidik dan tenaga kependidikan pernah mengikuti diklat berjenjang tingkat lanjut.

Apabila kita lihat dari hasil keseluruhan para lulusan pendidik dan tenaga kependidikan masih jauh dari harapan, ini menjadi sebuah kendala dan masalah yang harus segera di tindak lanjuti demi terciptanya pendidik yang profesional walaupun pada kenyataannya HIMPAUDI banyak mengalami berbagai macam kendala di lapangan. Oleh karena itu, dibutuhkan seorang pemimpin yang dapat menjaga keseimbangan struktur organisasi sehingga kejadian tak terduga tidak terjadi sehingga kesenjangan dalam negosiasi dapat diselesaikan dan tujuan organisasi yang efektif dapat dicapai. (Hartog \& Koopman, 1997). Kekuatan dan otoritas pemimpin diperlukan untuk memainkan peran utama atau sentral dalam mempengaruhi semua anggota (Conger; Kanungo \& Mathur, 1997).

Berdasarkan observasi awal, upaya yang dilakukan HIMPAUDI selama ini bertujuan untuk meningkatkan profesional pendidik PAUD. Perjuangan masih harus terus dilakukan dn amanah masih harus terus dijalankan karena organisasi ini tumbuh dari masyarakat, oleh masyarakat, untuk masyarakat yang tercermin dalam kegiatan-kegiatan yang dilakukan organisasi HIMPAUDI bekerjasama dengan mitra organisasi, pihak swasta dan Pemerintah Daerah. Pendidik dan tenaga kependidikan secara terus menerus mencoba menggali potensi dirinya demi terbentuknya pendidik profesional, meskipun tidak ditempuh dengan jenjang pendidikan formal.

\section{KAJIAN PUSTAKA}




\section{a. Organisasi HIMPAUDI}

HIMPAUDI merupakan suatu organisasi independen yang menghimpun unsur pendidik dan tenaga kependidikan anak usia dini. Pendidik anak usia dini adalah tenaga yang berperan menjadi panutan, pembimbing, pengasuh dan fasilitator bagi anak usia dini. Pendidik bagi anak usia dini disebut pendidik (guru). Sedangkan tenaga kependidikan adalah pengelola, pemerhati, pakar, praktisi dan masyarakat umum lainnya yang melaksanakan program PAUD. Dasar hukum terbentuknya HIMPAUDI adalah Undang-Undang Sistem Pendidikan Nasional Nomor 20 tahun 2003 pasal 14 secara tegas dinyatakan bahwa pendidikan anak usia dini adalah upaya pembinaan yang ditujukan kepada anak sejak lahir (0) sampai usia (6) tahun yang dilakukan melalui pemberian rangsangan pendidikan untuk membantu pertumbuhan dan perkembangan jasmani dan rohani agar anak memiliki kesiapan dalam memasuki pendidikan yang lebih lanjut.

Tujuan berdirinya HIMPAUDI adalah untuk membantu menangani tugas-tugas yang tidak mungkin dapat dilakukan oleh pemerintah karena keterbatasan sumber daya manusia. Selain itu terbentuknya HIMPAUDI diharapkan dapat menjadi wadah bagi para pendidik dan tenaga kependidikan untuk saling asah, asih dan asuh dalam rangka meningkatkan mutu program pendidikan anak usia dini secara optimal di seluruh Indonesia dan mengoptimalkan pemahaman dan pengembangan pengetahuan serta keterampilan tentang program pendidikan anak usia dini yang selama ini dirasa masih kurang. Dalam menjalani fungsinya HIMPAUDI berupaya untuk mempersatukan para pendidik dan tenaga kependidikan anak usia dini di Indonesia, meningkatkan kualitas PAUD sesuai dengan konsep dasar pembinaan tumbuh kembang anak secara holistik. Dalam AD pasal 17 diungkapkan tentang struktur organisasi HIMPAUDI berjenjang dari tingkat pusat, tingkat wilayah, tingkat daerah, dan tingkat cabang.

\section{b. Kepemimpinan}

Suatu organisasi tidak dapat dipisahkan dari peran seorang pemimpin/ketua yang memiliki andil besar dalam kemajuan/kemunduran organisasi. Ini tidak mungkin untuk membedakan kepemimpinan dan pemerintahan karena ini adalah kesatuan. Seorang kepala perlu memiliki rasa kepemimpinan. Semangat kepemimpinan ini dikembangkan dari waktu ke waktu dari satu fase hingga akhirnya mengkristal menjadi sejenis karakteristik kepemimpinan (Ladd, 2011). Pemimpin yang baik adalah pemimpin yang dapat menyelesaikan masalah dalam tubuh organisasi dan masalah di anggotanya (Grissom, Kalogrides \& Loeb, 2012). Elemen paling penting dalam teori kepemimpinan adalah keberadaan posisi dan kekuatan dominan yang dapat memberikan dukungan dan keamanan (Yakub; Goddard; Kim; Miller \& Goddard, 2015). Safaria (2003) menggambarkan seorang pemimpin sebagai seseorang dalam satu organisasi yang memiliki peran sentral. Elemen paling penting dalam teori kepemimpinan adalah kehadiran posisi dan kekuatan dominan yang dapat memberikan dukungan dan keamanan (Podsakoff; MacKenzie \& Bommer, 1996). Kepemimpinan seseorang akan terlihat jika ada sekelompok orang yang didorong menuju tujuan bersama dengan mengakui keberadaan otoritas pemimpin.

Seorang pemimpin harus memiliki berbagai keterampilan kepemimpinan untuk mencapai tujuan organisasi. Seorang pemimpin harus selalu mengambil inisiatif dan memberikan insentif untuk perubahan dan tanggung jawab aktivitas organisasi (Winardi, 2009). Pemimpin juga harus mampu membuat rencana, memperoleh pengetahuan, membangun kepercayaan, dan menginspirasi tindakan saat melakukan tugas kepemimpinan. Lahirnya penegasan sikap kepemimpinan pada dirinya akan dibantu oleh seseorang yang memiliki jiwa kepemimpinan dengan upaya gigih (Fahmi, 2012). Dalam prosesnya, apa yang disebut paradigma kepemimpinan yang karismatik dan transformatif adalah karakter yang mutlak harus dimiliki oleh seorang pemimpin (Weber, 1947 dalam Beyer, 1999) dan membubarkan kekayaan dan kekhasannya dalam proses tersebut. Factor kepemimpinan seseorang dipandang sebagai penentu utama terhadap efektivitas kinerja suatu organisasi, tetapi ada efek sebab akibat yang diakibatkan dari perilaku pemimpin pada proses organisasi yang akhirnya menentukan efektivitas organisasi jarang dijelaskan secara rinci.

Secara obyektif, kepemimpinan seseorang akan terlihat jika ada kecerdasan, inspirasi, kepercayaan diri, penilaian yang baik, superioritas, agresi, kelancaran, dan pengambilan keputusan yang cepat (Yukl, 1999). Selain itu, penyebab intrinsik, kesadaran, dan karakteristik juga akan sangat mempengaruhi kepemimpinan seorang individu, semakin menambah bobot, nilai, kekuatan, dan keterampilan bagi para pemimpin (Goddard; Hoy, W. K; Hoy, A. W, 2004). Dalam konteks ini HIMPAUDI membutuhkan sosok pemimpin yang memiliki kemampuan memimpin dengan gaya kepemimpinan yang 
transformasional dan transaksional. Kepemimpinan transformasional adalah sejenis gaya kepemimpinan yang mengarah pada perubahan positif pada anggotanya sedangkan kepemimpinan transaksional adalah gaya kepemimpinan di mana seorang pemimpin berfokus pada interaksi interpersonal dengan anggotanya (Beyer, 1999). Secara umum, pemimpin tersebut harus kreatif, antusias, dan bersemangat. Para pemimpin tidak hanya memperhatikan proses dan terlibat di dalamnya, tetapi mereka juga fokus untuk membantu setiap anggota kelompok untuk berhasil. Bass (1996) berpendapat bahwa kepemimpinan transformasional dan transaksional dapat bersifat direktif (otokratis) atau partisipatif, tetapi ini adalah argumen yang lemah untuk mengecualikan perilaku yang tampaknya sangat relevan dengan proses pengaruh yang mendasari kepemimpinan transformasional. Seperti kebanyakan teori dari kepemimpinan, teori kepemimpinan transformasional mencerminkan asumsi implisit yang terkait dengan stereotip "kepemimpinan heroic" (Calder, 1977; Meindl, Ehrlich, \& Dukerich, 1985).

\section{c. Kompetensi Guru Profesional}

Guru memegang peranan yang sangat penting dalam sebuah proses pendidikan, guru juga merupakan salah satu tolak ukur berhasil atau tidaknya proses pendidikan yang dilakukan. Bila para guru yang ada dalam sebuah lembaga pendidikan mampu untuk mengemban tugasnya secara profesional, maka apa yang menjadi tujuan pembelajaran akan semakin mungkin untuk digapai. Untuk menyandang gelar guru profesional tentu banyak indikator yang harus dimiliki oleh guru tersebut agar layak dikatakan sebagai guru yang profesional, termasuk salah satunya yaitu kompetensi yang harus dia miliki sebagai seorang guru(Tetep, 2015). Seorang pendidik harus memiliki 4 kemampuan atau kompetesi yang benar-benar dikuasai yaitu kompetensi profesional, kompetensi pedagogik, kompetensi kepribadian dan kompetensi sosial. Kompetensi profesional guru diartikan sebagai kebulatan pengetahuan, keterampilan, dan sikap yang diwujudkan dalam bentuk tindakan cerdas dan penuh tanggung jawab yang dimiliki seseorang yang memangku jabatan guru sebagai profesi. Dalam melakukan tugas, ataupun pekerjaan kita telah dituntut memiliki kemampuan profesional atau potensi profesional. Kemampuan tersebut sebagai sarana penunjang lancarnya sebuah tugas atau pekerjaan yang telah dikerjakan dan mampu diselesaikan dengan baik yang berkaitan dengan suatu hal berdasarkan kemampuan yang dimiliki untuk mata pencahariannya. Kompetensi profesional merupakan salah satu faktor pendukung dalam meningkatkan kualitas seorang guru yang harus terus dikembangkan sesuai dengan perkembangan kebutuhan yang ada di lingkungan. Kompetensi profesional guru mencakup pemahaman tentang keilmuan yang mereka pahami dan mereka ajarkan. (Wahyudi, 2010. Standar Kompetensi Profesional Guru. Jurnal Pendidikan Sosiologi Dan Humaniora Vol. 1 (2), hal: 1-13).

Kompetensi yang ada dan dapat dinilai profesional ketika ia mampu memenuhi tanggung jawabnya dengan baik. Misalnya saja pada seorang guru yang memiliki tenaga profesional untuk mendidik anak didiknya, guru dituntut untuk menjadi tenaga yang profesional dalam memberikan pengetahuannya pada anak didik. Profesional merupakan suatu sifat dasar yang dimiliki oleh seorang individu tentang pengetahuan serta wawasan dalam suatu bidang tertentu dan sebagai dasar dari profesionalitas inividu sebagai unit tunggal dan memiliki keragaman yang melekat. Selain itu, memberikan pengaruh perubahan untuk mengetahui secara tepat dalam menghadapi dengan pemahaman yang baik dan mampu mengatasi berbagai perubahan dalam ilmu pengetahuan. (Evans; Linda 2008).

Dalam undang-undang Guru dan dosen (pasal 1 ayat 4) disebutkan bahwa profesional adalah pekerjaan atau kegiatan yang dilakukan oleh seseorang dan menjadi sumber penghasilan kehidupan yang memerlukan keahlian, kemahiran, atau kecakapan yang memenuhi standar mutu dan norma tertentu serta memerlukan pendidikan profesi. Selanjutnya dikatakan bahwa kompetensi profesional adalah "kemampuan penguasaan materi pelajaran secara luas dan dalam". Dalam hal ini, kompetensi profesional adalah berbagai kemampuan yang diperlukan adar dapat mewujudkan dirinyansebagai guru profesional. Kompetensi profesional meliputi kepakaran atau keahlian dalam bidangnya yaitu penguasaan bahan yang harus diajarkan, metode, rasa tanggung jawab akan tugasnya dan rasa kebersamaan dengan sejawatnya. 
Pengembangan profesional tersebut akan selalu mengikuti informasi pengembangan IPTEK yang mendukung profesi melalui berbagai kegiatan ilmiah. Seorang guru hendaknya dapat mengembangkan berbagai model pembelajaran yang bervariatif dan tidak membosankan sehingga efektifitas belajar dapat terus ditingkatkan. Kemampuan guru dalam menulis juga harus selalu ditingkatkan, misalnya dalam menulis makalah, menulis buku pelajaran, menyusun diktat pelajaran, menulis modul dan menulis karya ilmiah, melakukan penelitian ilmiah, yang diiringi dengan penerapan teknologi tepat guna serta memanfaatkan alat peraga/media hingga menciptakan karya seni. Yang tidak kalah penting adalah bahwa guru dituntut untuk mengembangkan profesi dengan mengikuti pelatihan terakreditasi, pendidikan kualifikasi, dan kegiatan pengembangan kurikulum. Pemahaman wawasan dalam kompetensi profesional menuntut guru untuk memahami visi dan misi, hubungan pendidikan dan pengajaran, konsep pendidikan dasar dan menengah serta fungsi sekolah. Selain itu, mereka diharapkan dapat mengidentifikasi permasalahan dalam hal proses dan hasil belajar serta membangun sistem yang menunjukkan keterkaitan pendidikan dalam dan luar sekolah. Terakhir, bahan ajar kajian akademik dapat dikuasai oleh guru sehingga mereka memahami struktur pengatahuan dan menguasi substansi materi serta menguasai substansi kekuasaaan sesuai dengan jenis pelayanan yang dibutuhkan siswa.

Sementara di dalam pasal (7) ayat (1) dikatakan bahwa profesi guru dan dosen merupakan bidang pekerjaan khusus yang memerlukan prinsip-prinsip profesional sebagai berikut :

a. Memiliki bakat, minat, panggilan jiwa, dan idealisme;

b. Memiliki kualifikasi pendidikan dan latar belakang sesuai dengan bidang tugasnya;

c. Memiliki kompetensi yang diperlukan sesuai dengan bidang tugasnya;

d. Mematuhi kode etik profesi;

e. Memiliki hak dan kewajiban dalam melaksanakan tugas;

f. Memperoleh penghasilan yang ditentukan sesuai dengan prestasi kerjanya;

g. Memiliki kesempatan untuk mengembangkan profesinya secara berkelanjutan;

h. Memperoleh perlindungan hokum dalam melaksanakan tugas profesionalnya;

i. Memiliki organisasi profesi yang berbadan hukum.

Menurut Suyanto dan Jihad (2013:20) Profesionalisme adalah sebutan yang mengacu pada sikap mental dalam bentuk komiten anggota suatu profesi untuk senantiasa mewujudkan dan meningkatkan kualitas profesionalnya. Seorang guru akan melakukan berbagai cara dan strategi didalam upaya mengembangkan kemampuannya sesuai dengan perkembangan zaman sekaligus menunjukkan profesionalismenya sebagai guru/pendidik.

Guru profesional adalah guru yang memiliki kompetensi yang dipersyaratkan untuk melakukan tugas pendidikan dan pengajaran. Menurut Kunandar (2009:77) "kompetensi profesional merupakan penguasaan materi pembelajaran secara luas dan mendalam, yang mencakup penguasaan materi kurikulum mata pelajaran di sekolah dan subtansi keilmuan yang menaungi materinya, serta penguasaan terhadap struktur dan metodologi keilmuannya". Indikatornya sebagai berikut:

a. Memahami materi ajar yang ada dalam kurikulum sekolah;

b. Memahami struktur, konsep, dan metode keilmuan yang menaungi atau koheren dengan materi ajar;

c. Menerapkan konsep-konsep keilmuan dalam kehidupan sehari-hari.

Guru profesional harus mampu menguasai ilmu pengetahuan tentang bahan yang diajarkan, karakteristik siswa, metode, dan sumber bahan. Menurut Uno (2012:64) guru yang memilki kompetensi profesional perlu menguasai antara lain:

a. Disiplin ilmu pengetahuan sebagai sumber bahan ajaran;

b. Bahan ajar yang diajarkan;

c. Pengetahuan tentang karakteristik siswa;

d. Pengetahuan tentang filsafat dan tujuan pendidikan;

e. Pengetahuan serta penguasaan metode dan model mengajar;

f. Penguasaan tentang prinsip-prinsip teknologi pembelajaran;

g. Pengetahuan terhadap penilaian, mampu merencanakan dan memimpin, guna kelancaran proses pendidikan.

Profesionalisme guru merupakan suatu kebutuhan di dalam sebuah profesi yang menuntut kecakapan dan keahlian yang dimilikinya agar dapat berperan secara maksimal seiring dengan semakin meningkatnya persaingan di era globalisasi yang pada dasarnya juga merupakan keharusan bagi setiap individu dalam kerangka perbaikan kualitas hidup manusia. Profesionalisme menuntut keseriusan dan 
kompetensi yang memadai, sehingga seseorang dianggap layak untuk melaksanakan sebuah tugas (Tika, 2013:3). Pada hakekatnya pembinaan profesionalisme guru ditekankan pada tiga kemampuan dasar, yaitu : kemampuan profesi yaitu kemampuan dalam bidang profesi yang dimiliki oleh seorang tenaga ahli, kemampuan pribadi yaitu kemampuan mengenali dan memahami diri sendiri melalui pengalaman, wawasan dan sikap kita dalam kehidupan sehari-hari, dan kemampuan sosial yaitu kemampuan untuk mengelola emosi dirinya dengan orang lain dan mempunyai kepedulian antar sesama manusia sehingga bisa berinteraksi dengan baik (Supriadi, 2009).

Guru yang profesional tidak hanya dituntut untuk menguasai materi pembelajaran tetapi juga harus menguasi seluruh aspek dan harus mencakup ranah dalam pembelajaran seperti aspek kognitif (berfikir), aspek afektif (perilaku), dan aspek psikomotor (keterampilan) karena melibatkan peserta didik (Asmarani, 2014:504). Profesionalisme guru dapat dilakukan dengan berbagai cara, pertama; dengan memenuhi tuntutan standar profesi yang ada, kedua; mencapai kualifikasi dan kompetensi yang dipersyaratkan, ketiga; membangun hubungan kesejawatan yang baik dan luas termasuk lewat organisasi profesi, keempat; mengembangkan etos kerja atau budaya kerja yang mengutamkan pelayanan bermutu tinggi kepada konstituen, kelima; mengadopsi inovasi atau mengembangkan kreatifitas dalam pemanfaatan teknologi komunikasi dan informasi mutakhir agar senantiasa tidak ketinggalan dalam kemampuannya mengelola pelajaran (Muhson: 2014:97). Profesional guru perlu terus dikembangkan sesuai dengan kebutuhan, karena akan terus menemukan generasi yang terus berkembang di dalam pelaksanaan pembelajaran. Profesionalisme pendidik ditunjang oleh kualitas dan sikap yang harus bisa dipertanggung jawabkan baik untuk dirinya maupun kehidupan sosialnya di lingkungan masyarakat secara umum. Hal ini dapat ditunjukkan dengan sikap menampilan perilaku yang mendekati standar ideal yang secara sadar dilakukan untuk meningkatkan dan memelihara citra profesi dalam mengejar kesempatan untuk mengembangkan kompetensi profesional serta terus berupaya memperbaiki kualitas pengetahuan dan keterampilannya sebagai seorang pendidi sehingga menimbulkan kebanggaan tersendiri terhadap profesi yang digelutinya (Sagala, 2009).

\section{METODE PENELITIAN}

Pendekatan yang digunakan dalam penelitian merupakan pendekatan kualitatif dengan metode deskriptif analitik, yaitu pendekatan yang tidak mengandung angka-angka, melainkan berupa kata-kata, gambar, dan sebagainya. Bogdan dan Taylor (Moleong, 2007:17) mengatakan bahwa "Pendekatan kualitatif merupakan sebagai prosedur penelitian yang menghasilkan data deskriptif, berupa kata-kata tertulis atau lisan dari orang-orang dan perilaku yang dapat diamati”. Dalam penelitian ini, peneliti menekankan padaS faktor peneliti sebagai alat penelitian utama, disamping memperhatikan metode yang digunakan, agar hasilnya sesuai dengan apa yang diharapkan.

\section{HASIL DAN PEMBAHASAN}

1. Implementasi Kepemimpinan Ketua HIMPAUDI Dalam Peningkatan Pofesionalisme Pendidik PAUD Non-Formal Terhadap Kualifikasi Pendidik

Berdasarkan hasil wawancara terhadap responden ketua Himpaudi kota Sukabumi membuat rencana kerja jangka pendek, menengah dan panjang yang berisikan peningkatan kompetensi guru diantaranya mengusulkan masuknya angaran beasiswa di RAPBD kota Sukabumi sehinggan beberapa guru PAUD dapat meningkatkan kulaifikasi pendidikanya secara gratis. Berdasarkan hasil observasi dilapangan terdapat beberapa guru PAUD yang belajar di Universitas Muhamadiyah Sukabumi dan beberapa kampus lain yang ada di wilayah sukabumi lewat pendanaan beasiswa PEMDA kota sukabumi, hal ini menunjukan peran ketua himpaudi dalam meningkatkan kompetensi guru PAUD khususnya kompetensi Profesional karena menurut undang-undan guru dan dosen harus minimal S1.

Dalam hal ini diperlukan peran ketua HIMPAUDI Kota Sukabumi dengan gaya kepemimpinan yang cermat, visioner dan kreatif dalam memotivasi anggota HIMPAUDI untuk meningkatkan kualitas pendidik PAUD. Hal ini hanya dapat dilakukan oleh kepemimpinan yang memiliki perilaku kepemimpinan karismatik yang dapat mengartikulasikan tujuan strategis kreatif, menunjukkan sensitivitas terhadap kebutuhan setiap bulan, menunjukkan perilaku yang tidak ortodoks, mengambil risiko pribadi, dan menunjukkan sensitivitas lingkungan (mengidentifikasi hambatan, bahaya, dan peluang) (Conger dan Kanungo, 1988). Karena jika ada pengakuan dari anggota yang kuat muncul, maka anggota bersedia untuk mendukung pemimpin yang karismatik dengan kemampuan luar biasa untuk menemukan solusi terhadap masalah-masalah yang mereka hadapi. 
2. Implementasi Metode Kepemimpinan Ketua HIMPAUDI Terhadap Peningkatan Profesionalisme Pendidik PAUD Non-Formal

Metode yang dilakukan ketua himpaudi untuk meningkatkan kompetensi guru PAUD Blewat pelatihan, pelatihan dan workshop diantaranya diklat dasar dan menengah yang secara rutin dilaksanakan tiap tahun. Untuk menunjang pengetahuan pendidik PAUD pengembangan kurikulum PAUD maka, tugas lain dari seorang ketua HIMPAUDI adalah mengadakan pelatihan-pelatihan PAUD yang berimplikasi terhadap program pembinaan PAUD. Karena pembelajaran di PAUD masih menitik beratkan pada pembelajaran calistung yang bernuansa akademik. Sehingga kebijakkan yang dibuat oleh Ketua HIMPAUDI ketika mengadakan pelatihan tentang model-model pembelajaran PAUD agar mampu meningkatkan profesionalisme pendidik saat mengajar.

Pengadaan pelatihan pengembangan kompetensi bagi pendidik selalu diadakan berkala setiap tahun untuk mendongkrak ingatan para pendidik dalam menguasai ilmu PAUD. Pelatihan yang dilaksanakan kurang lebih tiga kali dalam setahun yang penyelenggaraannya difasilitasi oleh Dinas Pendidikan dan Kebudayaan Kota Sukabumi atau oleh HIMPAUDI secara mandiri yang kemudian ditindak lanjuti setiap bulan di dalam pertemuan rutin PC HIMPAUDI di masing-masing Kecamatan. Kebijakankebijakan HIMPAUDI yang merujuk kepada Undang-undang dan program kerja HIMPAUDI juga diarahkan ke lembaga-lembaga PAUD non formal agar terus meningkatkan mutu lembaga yang sesuai dengan aturan penyelenggaraan PAUD non formal yang berprinsip pada pendidikan dan perkembangan anak usia dini. Penyelenggaraan PAUD non formal yang tersebar di Kota Sukabumi tidak telepas dari dukungan lapisan masyarakat yang menyadari pentingnya pendidikan untuk anak usia dini. Agar pemahaman masyarakat dalam hal ini orang tua yang mempunyai anak usia dini, pemerintah Kota Sukabumi melalui berbagai mitra organisasi profesi termasuk HIMPAUDI mengadakan juga pelatihan tentang parenting sebagai panduan para orangtua untuk meningkatkan partisipasi pendidikan anak baik di satuan pendidikan maupun di rumah. Keterlibatan orangtua dalam PAUD sangat penting dan mempengaruhi tingkat kebiasaan anak dalam kehidupan sehari hari. Kegiatan keorangtuaan ini tidak hanya menjelaskan tentang bagaimana cara mengasuh, mendidik atau membimbing anak saja, tetapi juga tentang bagaimana memberikan asupan gizi dan perlindungan yang baik menurut Undang-undang perlindungan anak. Orangtua perlu mengetahui dan memahami prinsip penyelenggaraan PAUD yang tidak menitikberatkan kepada nilai akademik tetapi lebih kepada pembiasaan dan pembangunan karakter pada anak usia dini.

3. Implementasi Kebijakan Ketua HIMPAUDI Terhadap Peningkatan Profesional Pendidik PAUD

Non-Formal

Kebijakan ketua himpaudi kota sukabumi dalam implemntasinya berusaha meningkatkan kesejahteraan bagi pendidik PAUD non formal di Kota Sukabumi melalui pemberian bantuan dana insentif bagi pendidik PAUD yang memenuhi syarat seperti TMT dan sudah memiliki sertifikat berjenjang sebagai calon penerima dari Pemerintah Pusat dan Wilayah. Saat ini Pemerintah Kota Sukabumi sudah memberikan dana stimulan setiap dua kali dalam setahun untuk pendidik walaupun masih dalam jumlah yang belum realistis dengan tanggung jawab yang diemban para pendidik. Hal ini memang perlu disadari apabila dikaitkan dengan kualitas pendidik PAUD Kota Sukabumi yang latar belakang pendidikannya masih beragam. Tapi ini sudah dapat membuktikan bahwa ada upaya dari Pemerintah dalam mensejahterakan para pendidik PAUD di lingkungan Kota Sukabumi.

Ketua HIMPAUDI bermitra dengan pemerintah untuk membantu menangani tugas-tugas yang tidak mungkin dapat dilakukan karena keterbatasan sumber daya manusia. Selain itu terbentuknya HIMPAUDI diharapkan dapat menjadi wadah bagi para pendidik dan tenaga kependidikan untuk saling asah, asih dan asuh dalam rangka meningkatkan mutu program pendidikan anak usia dini secara optimal di seluruh Indonesia dan mengoptimalkan pemahaman dan pengembangan pengetahuan serta keterampilan tentang program pendidikan anak usia dini yang selama ini dirasa masih kurang sehingga muncul permasalahan yang menyangkut kualitas, baik dari aspek layanan maupun kualitas pendidik. Pendidik memiliki latar belakang pendidikan yang sangat bervariasi dan tidak sesuai dengan persyaratan dan juga masih banyak yang berpendidikan rendah. Permasalahan lain yang muncul menyangkut kesejahteraan pendidik PAUD yang memprihatinkan, dimana pendapatannya masih jauh di bawah upah minimum provinsi (UMP) serta belum diakuinya profesi pendidik PAUD.

HIMPAUDI didirikan untuk menghimpun aspirasi dan meningkatkan profesionalitas pendidik dan tenaga kependidikan anak usia dini Indonesia (pasal 9 Anggaran Dasar HIMPAUDI) yang berfungsi sebagai wadah untuk mempersatukan pendidik dan tenaga kependidikan anak usia dini, meningkatkan 
kualitas pendidik dan tenaga kependidikan anak usia dini, serta memperjuangkan peningkatan kesejahteraan dan perlindungan bagi pendidik dan tenaga kependidikan anak usia dini (pasal 10 Anggaran Dasar). Dalam menjalani fungsinya HIMPAUDI berupaya untuk mempersatukan para pendidik dan tenaga kependidikan anak usia dini di Indonesia, meningkatkan kualitas pendidikan anak usia dini sesuai dengan konsep dasar pembinaan tumbuh kembang anak secara holistik. Dalam AD pasal 17 diungkapkan tentang struktur organisasi HIMPAUDI berjenjang dari tingkat pusat, tingkat wilayah, tingkat daerah, dan tingkat cabang.

\section{KESIMPULAN}

Secara umum HIMPAUDI dibentuk untuk membantu pemerintah menangani tugas-tugas yang tidak mungkin dapat dilakukan karena keterbatasan sumber daya manusia. Ketua Himpaudi kota Sukabumi membuat rencana kerja jangka pendek, menengah dan panjang yang berisikan peningkatan kompetensi guru diantaranya mengusulkan masuknya angaran beasiswa di RAPBD kota sukabumi sehinggan beberapa guru PAUD dapat meningkatkan kulaifikasi pendidikanya secara gratis.

Motode yang dilakukan ketua himpaudi untuk meningkatkan kompetensi guru PAUD Blewat pelatihan, pelatihan dan workshop diantaranya diklat dasar dan menengah yang secara rutin dilaksanakan tiap tahun. Untuk menunjang pengetahuan pendidik PAUD pengembangan kurikulum PAUD maka, tugas lain dari seorang ketua HIMPAUDI adalah mengadakan pelatihan-pelatihan PAUD yang berimplikasi terhadap program pembinaan PAUD. Karena pembelajaran di PAUD masih menitik beratkan pada pembelajaran calistung yang bernuansa akademik. Sehingga kebijakkan yang dibuat oleh Ketua HIMPAUDI ketika mengadakan pelatihan tentang model-model pembelajaran PAUD agar mampu meningkatkan profesionalisme pendidik saat mengajar.

\section{DAFTAR PUSTAKA}

Sumber buku :

[1] Basrowi \& Soenyono. (2007). Metode Analisis Data Sosial. Kediri: Jenggala Pustaka Utama

[2] Bass, B. M., \& Avolio, B. J. (1990). Multifactor Leadership Questionnaire. Palo Alto, CA: Consulting Psychologists Press.

[3] Bass, B. M. (1996). A New Paradigm of Leadership: An Inquiry into Transformational Leadership. Alexandria, VA: U. S. Army Research Institute for the Behavioral and Social Sciences.

[4] (2000). Leadership and Performance Beyond Expections. Free Press, Newyork, NY.

[5] Calder, B. J. (1977). An Attribution Theory of Leadership. In B. M. Staw \& G. R. Salancik (Eds.), New Direction In Organizational Behavior. Chicago: St. Clair.

[6] Conger, J. A. \& R. A. Kanungo. (1988). Charismatic leadership: The elusive factor in organizational effectiveness (pp. 122-160). San Francisco, CA: Jossey-Bass.

[7] Evans, J.R. and Lindsay, W. M. (2005). The Manajement and Control of Quality, Sixth Edition. Singapore: Thomson South Westren.

[8] Hunt, J. G. (1991). Leadership: A New Synthesis. Newbury Park: Sage Publications.

[9] Kunandar. (2010). Guru Profesionalisme. Jakarta: Rajawali Press.

[10] Mas'ud, Fuad. (2004). Survai Diagnosis Organisasi, Konsep, dan Aplikasi. Semarang: BP Undip.

[11] Moleong, L. J. (2004). Metode Penelitian Kualitatif. Bandung: Remaja Rosdakarya.

[12] Sagala, S. (2009). Konsep dan Makna Pembelajaran. Bandung: Alfabeta.

[13] Supriyadi, Dedi. (2008). Mengangkat Citra dan Martabat Guru. Yogyakarta: Adicita Karya Nusa.

[14] Suyanto, Jihad. (2013). Menjadi Guru Profesional. Strategi Meningkatkan Kualifikasi dan Kualitas guru di Era Global. Jakarta: Erlangga

[15] Uno, Hamzah. (2007). Teori Motivasi dan Pengukurannya: Analisis di Bidang Pendidikan. Jakarta: Bumi Aksara. 
[16] Wahyudi, Iman. (2012). Mengejar Profesionalisme Guru Strategis Praktis Mewujudkan Citra Guru Profesional. Jakarta: Prestasi Jakarta.

[17] Wahyudi. (2010). Standar Kompetensi Profesional Guru. Jurnal Pendidikan Sosiologi Dan Humaniora 1 (2), pp. 1-13

[18] Wahyudi. (2012). Kepemimpinan Kepala Sekolah Dalam Organisasi Pembelajar (Learning Organization). Bandung: Alfabeta.

[19] Yukl, G. (1998). Leadership in Organizations (4th ed). Englewood Cliffs, NJ: Prentice Hall.

Sumber Jurnal :

[20] Asmarani, Nur'aeni.(2014). Peningkatan Kompetensi Profesional Guru Sekolah Dasar. Jurnal Administrasi Pendidikan. 2(1), 503-510.

[21] Beyer, J. M. (1999). Taming and Promoting Charisma to Change Organizations. The Leadership Quarterly, 10(2), 307-330. doi:10.1016/s1048-9843(99)00019-3

[22] Conger, J. A., Kanungo, R. N., Menon, S. T., \& Mathur, P. (2009). Measuring Charisma: Dimensionality and Validity of the Conger-Kanungo Scale of Charismatic Leadership. Canadian Journal of Administrative Sciences/Revue Canadienne Des Sciences de l'Administration, 14(3), 290-301. doi:10.1111/j.1936-4490.1997.tb00136.x

[23] Goddard, R. D., Hoy, W. K., \& Hoy, A. W. (2004). Collective Efficacy Beliefs: Theoretical Developments, Empirical Evidence, and Future Directions. Educational Researcher, 33(3), 3-13. doi:10.3102/0013189x033003003

[24] Grissom, J. A., Kalogrides, D., \& Loeb, S. (2012). Using Student Test Scores to Measure Principal Performance (NBER Working Paper No. 18568). National Bureau of Economic Research. Retrieved from http://www.nber.org/papers/w18568

[25] Hartog, D. N., Muijen, J. J., \& Koopman, P. L. (1997). Transactional Versus Transformational Leadership: An Analysis of the MLQ. Journal of Occupational and Organizational Psychology, 70(1), 19-34. doi:10.1111/j.2044-8325.1997.tb00628.x

[26] Jacob, R., Goddard, R., Kim, M., Miller, R., \& Goddard, Y. (2015). Exploring the Causal Impact of the McREL Balanced Leadership Program on Leadership, Principal Efficacy, Instructional Climate, Educator Turnover, and Student Achievement. Educational Evaluation and Policy Analysis, 37(3), 314-332. doi:10.3102/0162373714549620.

[27] Kelman, H. C. (1958). Compliance, Identification, and Internalization: Three Processes of Attitude Change. Journal of Conflict Resolution, 2, 51-56.

[28] Ladd, H. F. (2011). Teachers' Perceptions of Their Working Conditions: How Predictive of Planned and Actual Teacher Movement? Educational Evaluation and Policy Analysis, 33, 235-261. doi:10.3102/0162373711398128

[29] Meindl, J. R., Ehrlich, S. B., \& Dukerich, J. M. (1985). The Romance of Leadership. Administrative Science Quarterly, 30(1), 78. doi:10.2307/2392813

[30] Podsakoff, P. M., MacKenzie, S. B., \& Bommer, W. H. (1996). Transformational Leader Behaviors and Substitutes for Leadership as Determinants of Employee Satisfaction, Commitment, Trust, and Organizational Citizenship Behaviors. Journal of Management, 22(2), 259-298. doi:10.1177/014920639602200204

[31] Sutanto, A. (2002). Peran Budaya Organisasional Untuk Meningkatkan Kepuasan Kerja dan Kinerja Karyawan. Benefit, Jurnal Manajemen dan Bisnis. Vol. 6 (2), hal: 120 -129.

[32] Tampi, Bryan Johannes. (2017). Pengaruh Gaya Kepemimpinan Dan Motivasi Terrhadap Kinerja Karyawan Pada Pt. Bank Negara Indonesia, Tbk (Regional Sales Manado). Jurnal 3(4).

[33] Tediawati, J.M. (2011). “Peran HIMPAUDI Dalam Pengembangan PAUD”.17(1).

[34] Tetep, - (2015) Pengaruh Kompetensi Guru, Iklim Sekolah, Perhatian Orang Tua Dan Efektifitas Pembelajaran Ips Terhadap Pembentukan Karakter Sosial Peserta Didik. 
eprint_fieldopt_thesis_type_phd thesis, Universitas Pendidikan Indonesia. http://repository.upi.edu/view/creators/Tetep=3A-=3A=3A.html

[35] Yukl, G. (1999). An evaluation of conceptual weaknesses in transformational and charismatic leadership theories. The Leadership Quarterly, 10(2), 285-305. doi:10.1016/s1048-9843(99)00013-2

[36] Zarvedi, Reza; Rusli Yusuf; dan Mahdani Ibrahim. (2016). Pengaruh Kepemimpinan, Budaya Organisasi dan Kompetensi Terhadap Kinerja Pegawai Serta Implikasinya Pada Kinerja Kesekertariatan Kabupaten Pidie Jaya. Jurnal Perspektif Ekonomi Darussalam. Vol. 2 (2), hal: 1-17.

Sumber Undang Undang :

[37] Depdiknas. (2003). Undang-undang RI No. 20 Tahun 2003 tentang Sistem Pendidikan Nasional.

[38] Kemendikbud. (2011). Permendikbud No. 137 Tahun 2014 tentang Standar Nasional Pendidikan Anak Usia Dini. Jakarta: Kementerian Pendidikan dan Kebudayaan.

[39] Undang-Undang Dasar Negara Republik Indonesia 1945, Penjelasan Umum.

[40] Undang-Undang No. 14 Tahun 2005 tentang Guru dan Dosen Pasal 1 Butir 4, Pasal 7 Ayat 1. 